\title{
Arytenoid Cartilage Dislocation Caused by Neck Trauma
} Boyun Travması Sonucu Oluşan Aritenoid Kıkırdak Dislokasyonu

\author{
Mustafa TURAN ${ }^{1}$, Cemil KAVALCI $^{3}$, Mehmet ÜNALDI ${ }^{2}$, Haşmet YEĞIIN ${ }^{4}$, Ümit ASLAN ${ }^{1}$
}

1 Edirne Devlet Hastanesi, Acil Servis, Edirne

2 Kartal Lütfi Kırdar Eğitim Araştırma Hastanesi, Acil Tıp Kliniği, İstanbul

3 Ankara Numune Eğitim ve Araştırma Hastanesi, Acil Tıp Kliniği, Ankara

4 Edirne Devlet Hastanesi, Kulak Burun Boğaz Kliniği,Edirne

\section{ABSTRACT}

The mechanism of arytenoid dislocation theories are incomplete neuromuscular blockage, motor reactions during endotracheal intubation, or direct trauma to the cricoarytenoid joints. In this report, we present a case of arytenoid cartilage dislocation caused by falling on neck one hour ago.

Keywords: Arytenoid cartilage, dislocation, neck trauma, emergency room

\section{ÖZET}

Aritenoid çıkı ğı mekanizmaları arasında endotrakeal entübasyon sırasında nöromüsküler blokaj ya da cricoarytenoid eklemin doğrudan travması vardır. Bu yazıda, bir saat önce boyun bölgesinin üzerine düşmeden kaynaklanan aritenoid kıkırdak çıkığı olan bir olgu sunulmuştur.

Anahtar Sözcükler: Arytenoid Kartilaj, dislokasyon, boyun travması, acil servis

Başvuru Tarihi :29.12.2010 Kabul Tarihi : 06.02.2011 


\section{INTRODUCTION}

The mechanism of arytenoid dislocation theories are incomplete neuromuscular blockage, motor reactions during endotracheal intubation, or direct trauma to the cricoarytenoid joints leading to joint cavity hemorrhage or serosynovitis. ${ }^{1}$ In this report, we present a case of arytenoid cartilage dislocation caused by falling on neck one hour ago.

\section{CASE REPORT}

A thirty-one female, was admitted to the emergency service of the state Hospital, Edirne, with history of falling on neck one hour ago. Physical examination showed that the patient had a very long neck and very prominent thyroid cartilage. There was marked swelling and tenderness of the soft structures around the cartilage with considerable pain in the neck when the patient moved his head or neck in any direction. The patient had great difficulty in swallowing. There was slight embarrassment of respiration, but gradual improvement was noted within a few hours after injury. Fiberoptic laryngoscopy was performed by an otorhinolaryngologist and revealed anteromedial dislocation of the left arytenoid cartilage (Figure1-2). The patient did not consent to surgical treatment, and therefore conservative therapy was selected. Treatment consisted of absolute rest in bed with head, neck and shoulders elevated. Ice cap was applied locally to the neck until most of the swelling had subsided. prednisolon was given $2 \mathrm{mg} / \mathrm{kg}$ and Morphine (one-sixth of a grain). Patient was discharged from the hospital after 48 hours.
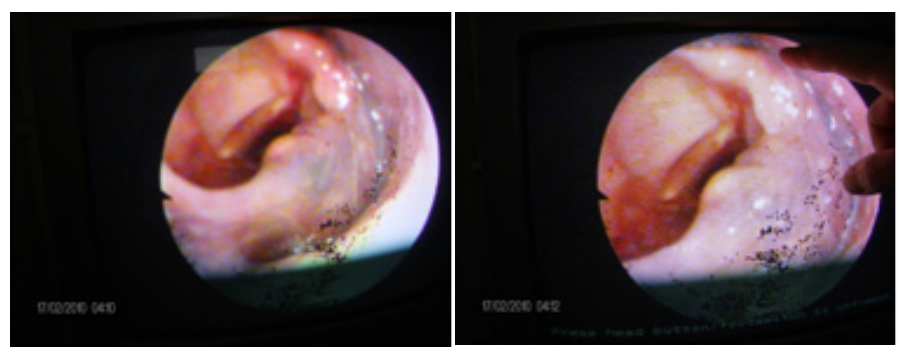

Figure 1-2: Fiberoptic laryngoscopy was performed by an otorhinolaryngologist and revealed anteromedial dislocation of the left arytenoid cartilage.

\section{DISCUSSION}

Some symptoms such as dysphagia, sore throat and may be caused by arytenoid cartilage dislocation. ${ }^{2}$ These complications include submucosal hemorrhage, granuloma formation, subglottic edema or laryngitis, impaired movement of one or both vocal folds caused by recurrent laryngeal nerve damage, and cricoarytenoid joint dysfunction, and may be characterized by hoarseness or stridor.1 Our patients had great difficulty in swallowing. Fiberoptic laryngoscopy was performed by an otorhinolaryngologist and revealed anteromedial dislocation of the left arytenoid cartilage.
The thyroid cartilage is more frequently involved than any part of the larynx. Soft structure injuries around the larynx are to be given great consideration. Severe or moderate soft structure injuries of the neck, associated with fractures of the larynx, are generally much more serious than direct injuries to the larynx with slight soft structure injury. ${ }^{1}$

Death is usually due to suffocation or sudden asphyxia, and in some cases to pneumonia. Sudden asphyxia may cause death before aid is secured. Emphysema of the neck is a very serious symptom. ${ }^{4}$ Close observation should be made for several days, because edema and suffocation take place in some cases several days following injury. At all times one should be prepared for an immediate tracheotomy. Tracheotomy should always be done (generally a low one) when the first signs of dyspnea and cyanosis are noticed. ${ }^{5,6}$ The patient did not consent to surgical treatment, and therefore conservative therapy was selected. Cold applications should be applied locally with absolute rest to the voice. ${ }^{6}$ Ice cap was applied locally to the neck until most of the swelling. Immediate attention should be given following injury; i.e, opiates, rest, and ice applied locally, thereby preventing serious complications in many instances. ${ }^{7}$ Two hours after medical treatment, the dislocated arytenoid cartilage had spontaneously repositioned and the patient regained his normal status.

\section{CONCLUSION}

Fracture of thyroid cartilage was occurred by hyperextension of the neck. This case is presented with its radiological findings because of interesting that it israre for occurrence mechanism.

\section{REFERENCES}

1. Mikuni I, Suzuki A, Takahata O, Fujita S, Otomo S, Iwasaki H. Arytenoid cartilage dislocation caused by a double-lumen endobronchial tube. Br J Anaesth 2006 ;96(1):136-8.

2. Sataloff RT, Bough ID Jr, Spiegel JR. Arytenoid dislocation: diagnosis and treatment. Laryngoscope 1994;104:1353-61.

3. Thal ER. Injury to the Neck. Trauma Second Ed. Moore EE, Mattox KL, Feliciano DV, Eds. Appleton \& Lange, Norwalk.1988:305-17.

4. Schild JA, Denneny EC. Evaluation and Treatment of Acute Laryngeal Fractures. Head Neck 1989;11(6): 491-6.

5. Senoglu N, Oksuz H, Ugur N, Dogan Z, Kahraman A. Arytenoid dislocation related to an uneventful endotracheal intubation: a case report Cases Journal 2008;1:251.

6. Saigusa H, Kokawa T, Aino I, Iwasaki C, Nakamura T, Yagi T. Arytenoid dislocation: a new diagnostic and treatment approach. J Nippon Med Sch 2003;70(5):382-3.

7. Bent JP 3rd, Porubsky ES. The Management of Blunt Fractures of the Thyroid Cartilage. Otolaringol Head Neck Surg 1994;110(2):195-202. 